\title{
SHEAR FLOW OF BOVINE SERUM ALBUMIN SOLUTIONS
}

\author{
MARIA BERCEA ${ }^{\mathrm{a}, *}$, SIMONA MORARIU, \\ IOANA-ALEXANDRA PLUGARIUa, DOINA BĂRÂLĂ ${ }^{b}$
}

\begin{abstract}
In this paper, the flow of bovine serum albumin (BSA) solutions in physiological serum was investigated at different concentrations from 1 to $10 \mathrm{~g} / \mathrm{dL}$ and temperatures from $4^{\circ} \mathrm{C}$ to $80^{\circ} \mathrm{C}$. Some peculiar behaviours were depicted as a function of thermodynamic and shear conditions. The intermolecular interactions, the electroviscous effects, the shear forces as well as the temperature influence the shear viscosity of BSA solutions.
\end{abstract}

Keywords: BSA, shear flow, shear induced aggregation, activation energy, associates

\section{INTRODUCTION}

Serum albumin, as a model for globular proteins, is synthesized by the liver in mammals and has a half-life in the circulatory system of approx. 19 days, being the most abundant globular protein in blood plasma (approx. 60\%) Its function is to bind and transport small molecules, such as fatty or amino acids, metals, dyes, or pharmaceutical compounds [1]. Bovine serum albumin (BSA) presents a high stability due to its primary structure of 585 amino acid residues and the secondary structure formed by $67 \% \alpha$-helix $[1,2]$.

The protein-protein interactions in solution in different concentration regimes attracted a high interest during the last years. Very often, the proteins are investigated in dilute solutions (bellow $0.1 \mathrm{~g} / \mathrm{dL}$ ) in order to understand their behaviour at molecular level. Efforts were carried out to evaluate the first order deviations from thermodynamic ideality in semidilute regime (between 0.1 and $1 \mathrm{~g} / \mathrm{dL}$ ) [3]. However, in physiological environment the protein content is of approx. 3.5-4.3 g/dL [4] or even higher, as for example the concentration of

\footnotetext{
a Petru Poni Institute of Macromolecular Chemistry, 41-A Grigore Ghica Voda Alley, 700487 lasi, Romania

b S.C. BARALCHIM S.R.L., Dumbravei Str., Nr. 17, 060044 Dumbrava Roşie, Romania

*Corresponding author bercea@icmpp.ro
} 
mammalian hemoglobin in erythrocytes can exceed $30 \mathrm{~g} / \mathrm{dL}$ [3]. A highly concentrated protein solution is generally considered the system in which more than $10 \%$ volume represents the solute (proteins can occupy up to $40 \%$ of the cellular volume). Usually, such solution is regarded as crowded [5], when the behaviour of the protein is influenced by the interactions with other like or unlike molecules [6]. Increased concentration leads to a smaller distance between the protein molecules and, as a consequence, the probability of protein-protein interactions is higher [7]. The resulting interactions are influenced by the net charge of the protein [8].

In salted solution, the deviation from the ideal behaviour is more pronounced as the protein concentration increases, structured aggregates appear due to short-range attractive interactions between protein molecules [3].

Small-angle X-ray scattering investigations have shown that at high protein concentrations, the balance between attractive and repulsive forces, controlled by $\mathrm{pH}$, influences the aggregation or extensive morphological changes [4]. Under physiological conditions (concentrations of $3.5 \mathrm{~g} / \mathrm{dL}-5.5 \mathrm{~g} / \mathrm{dL}$ ), the globular proteins keep the native structure in neutral and basic environments.

Globular proteins influence the flow properties, phase behaviour, microstructure and transport of biomolecules and biofluids in the mammalian body. These proteins are used in different formulations for food, drugs or cosmetics and the knowledge of their rheological behaviour is an important key in application of the multicomponent materials [9-11].

The present investigation is focused on flow behaviour of BSA in physiological serum at $\mathrm{pH}=7.4$, varying concentration from $1 \mathrm{~g} / \mathrm{dL}$ to $10 \mathrm{~g} / \mathrm{dL}$ and temperatures from $4^{\circ} \mathrm{C}$ to $80^{\circ} \mathrm{C}$.

\section{RESULTS AND DISCUSSION}

Figure 1 shows complete flow curves registered for $2 \mathrm{~g} / \mathrm{dL}$ BSA in physiological serum at $4^{\circ} \mathrm{C}$. The flow behaviour can be observed either from viscosity or shear stress as a function of shear rate. At low shear rates, the solution behaves as Newtonian fluid, the shear viscosity $(\eta)$ is independent on the applied shear rate $(\dot{\gamma})$. In this region, the relaxation time of the deformed solute is shorter than the characteristic time of the flow, keeping the rest structure of the solution which is formed by BSA associates and clusters. By increasing the shear rates, the BSA structures have no time to fully relax, the intermolecular interactions are in competition with the flow forces and the BSA molecules tend to orient along the flow direction. Thus, for shear rates in the range $0.0215 \mathrm{~s}^{-1}-100 \mathrm{~s}^{-1}$, the flow becomes non-Newtonian, the viscosity 
depends on the applied shear rate, varying as $\eta \sim \dot{\gamma}^{-0.79}$. At high shear rates $\left(\dot{\gamma}>100 \mathrm{~s}^{-1}\right)$, the intermolecular interactions are completely overcomed by the shear forces and the behaviour is again Newtonian.

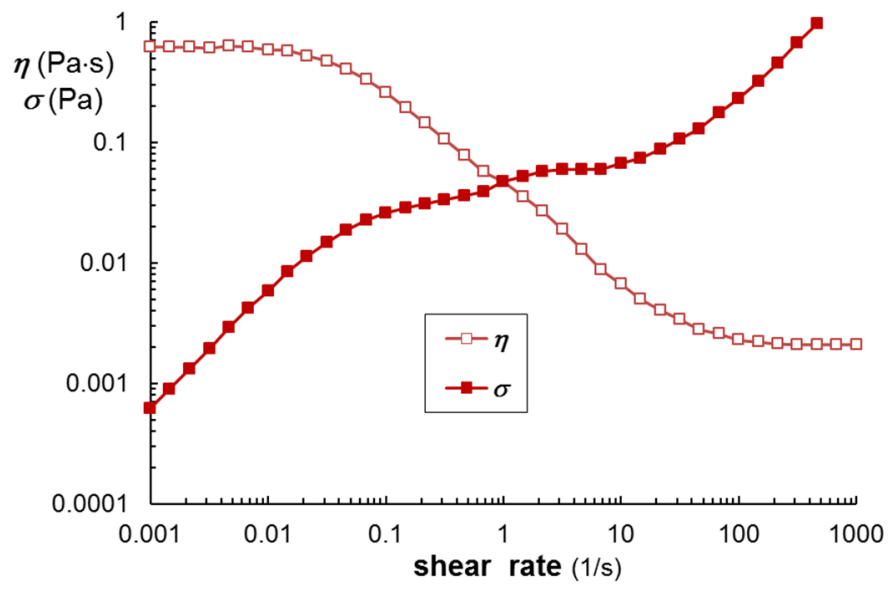

Figure 1. Viscosity and shear stress as a function of shear rate for $2 \%$ BSA solution at $4^{\circ} \mathrm{C}$

The flow curves are very sensitive to temperature as well as shear regime. As the temperature increases, the flow is Newtonian from $20^{\circ} \mathrm{C}$ to $45^{\circ} \mathrm{C}$ (Figure 2). For temperatures between $55^{\circ} \mathrm{C}$ and $65^{\circ} \mathrm{C}$ and $0.1 \mathrm{~s}^{-1}<\dot{\gamma}<$ $20 \mathrm{~s}^{-1}$, the curves present maxima due to shear induced aggregation occurring between BSA molecules. For $\dot{\gamma}>20 \mathrm{~s}^{-1}$, all curves show Newtonian behaviour. The shear induced aggregation was observed previously in dilute and semidilute polyelectrolyte aqueous solutions $[12,13]$. For BSA solutions, the electroviscous effects are in competition with Brownian motion, induced by temperature increase, and with the shear forces. At low temperatures and shear rates, the electroviscous effects are dominant for BSA concentrations up to $4 \mathrm{~g} / \mathrm{dL}$. The solution viscosity is influenced mainly by the charge of BSA molecules and counterions present in solution. Weak attractive interactions and long-range interactions exhibited at low concentrations coexist with the Coulombic and electroviscous repulsions and determine a shear thickening effect for moderate shear forces. High shear forces overcome these effects, the clusters and aggregates are destroyed and molecules flow easily and the viscosity approaches the second Newtonian region. At high concentrations, the contribution of attractive short-range interactions becomes significant and 
in salted solution the charge-induced repulsions are minimal $[7,14]$. At high temperatures $\left(70^{\circ} \mathrm{C}\right.$ and $\left.80^{\circ} \mathrm{C}\right)$, the predominance of attractive interactions induces a self-assembling behaviour of BSA molecules into a transient network with high resistance to flow (high viscosity of all systems, regardless concentration, Figure 3). Moreover, a heat denaturation with some changes in conformation of BSA molecules occurs, some aggregates are formed and a large unfolding takes place [15].

By following the viscosity at constant shear rate of $1 \mathrm{~s}^{-1}$ (similar to flow conditions of proteins in plasma of normal cells [16]) as a function of temperature for low BSA concentrations ( $1 \mathrm{~g} / \mathrm{dL}, 2 \mathrm{~g} / \mathrm{dL}$ and $4 \mathrm{~g} / \mathrm{dL}$ ), it can be observed that a sharp decrease occurs up to $20^{\circ} \mathrm{C}$, followed by a region where the viscosity slowly decreases as the temperature increases (Figure 3 ). Above $50^{\circ} \mathrm{C}-60^{\circ} \mathrm{C}$ one observes a maximum value of viscosity, then a decrease and a significant increase at $70^{\circ} \mathrm{C}$ and $80^{\circ} \mathrm{C}$. The full symbols represent the maxima from $\eta-\dot{\gamma}$ curves.

BSA presents in its structure 17 intrachain disulphide bridges and one sulfhydryl group (Cys-34) [2]. The disulphide bonds confer certain rigidity, but allow a significant conformational change under different external conditions. At neutral $\mathrm{pH}$, the disulphide bridges are hidden in the protein molecule and are not exposed to the solvent interactions.

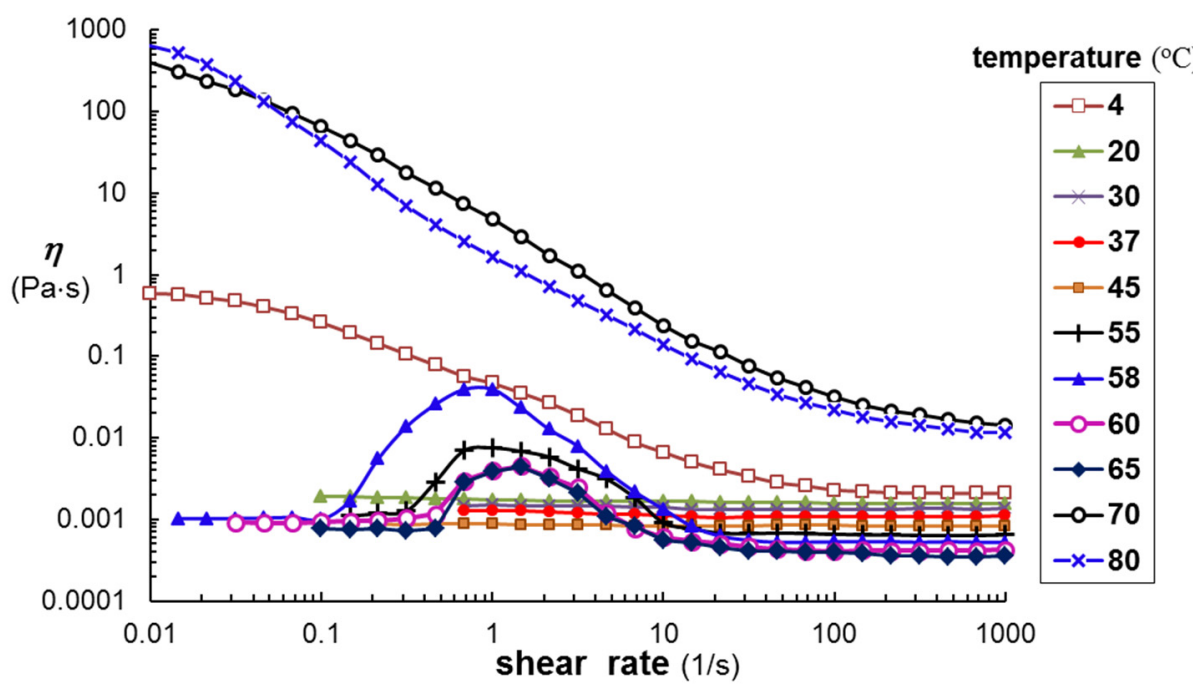

Figure 2. Viscosity as a function of shear rate for $2 \%$ BSA solution at various temperatures 


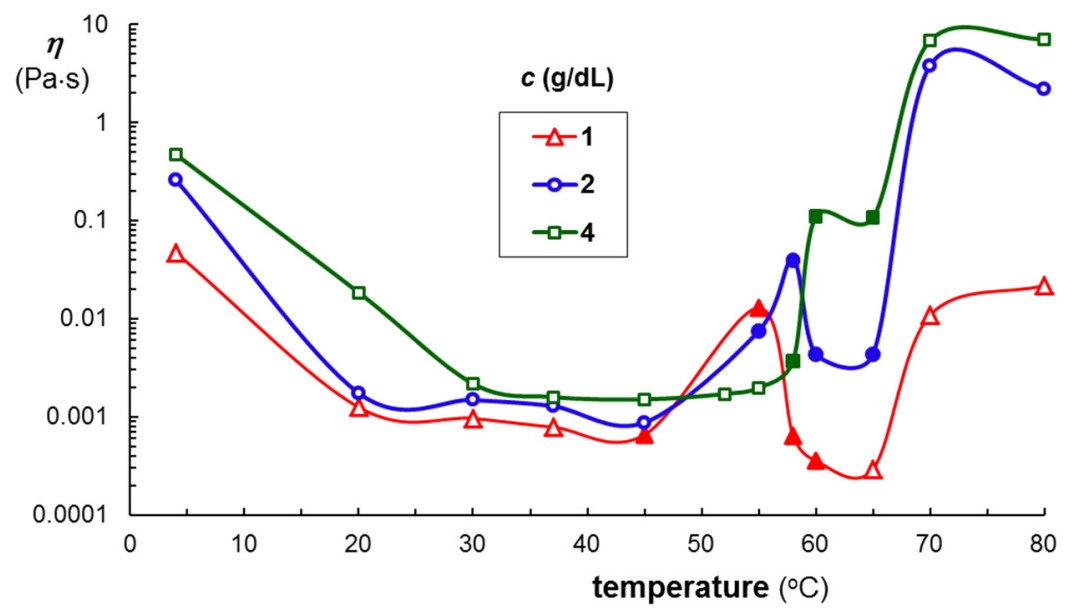

Figure 3. Viscosity as a function of temperature for $2 \%$ BSA solution at $1 \mathrm{~s}^{-1}$. The full symbols represent the maxima from $\eta-\dot{\gamma}$ curves

The activation energy of flow $\left(E_{a}\right)$ was determined from the plot of $\log \eta$ vs. 1/T (Figure 4), according to the Arrhenius equation:

$$
\eta=A \exp (E a / R T)
$$

where $\eta$ is the shear viscosity, $A$ is a pre-exponential factor, $R$ is the universal gas constant, $8.314 \mathrm{~J} /(\mathrm{K} \cdot \mathrm{mol})$, and $T$ is the absolute temperature $(\mathrm{K})$.

In this paper, for calculating $E_{a}$, we considered the value of shear viscosity at $100 \mathrm{~s}^{-1}$, this being the shear rate encountered in the case of hardened cells in solution containing albumin [16], and the range of temperatures from $20^{\circ} \mathrm{C}$ to $60^{\circ} \mathrm{C}$.

For BSA solutions, $E_{a}$ varies between $3.96 \mathrm{~kJ} / \mathrm{mol}$ for $1 \mathrm{~g} / \mathrm{dL}$ and 7.6 $\mathrm{kJ} / \mathrm{mol}$ for $10 \mathrm{~g} / \mathrm{dL}$ (Figure 5), values similar with those reported for polymer systems $[17,18]$.

The flow behaviour of the protein solutions is governed by the BSABSA interactions as well as interactions of the protein with the water and cosolute molecules, the hydrodynamic properties being strongly influenced by $\mathrm{pH}$ value and ionic strength of the solution [19], as well as the presence of other polymers [20]. The $\mathrm{pH}$ value is correlated with the charge of protein and with the protonation of ionizable amino acids. The presence of ions determines a screening of the electrostatic interactions [8]. 


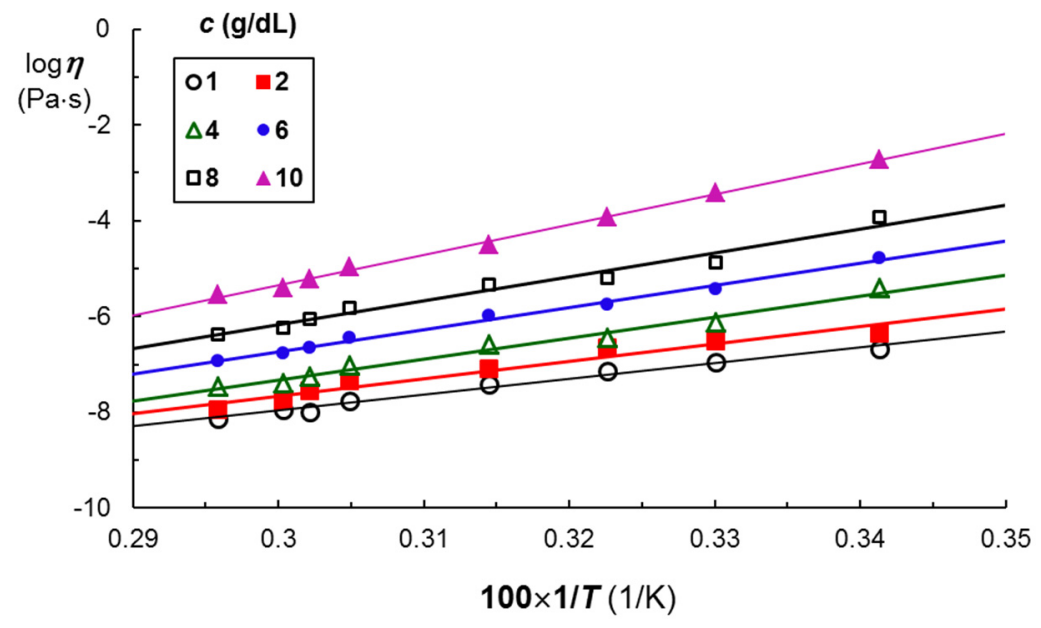

Figure 4. $\log \eta$ vs. $1 / T$ for BSA solutions of different concentrations

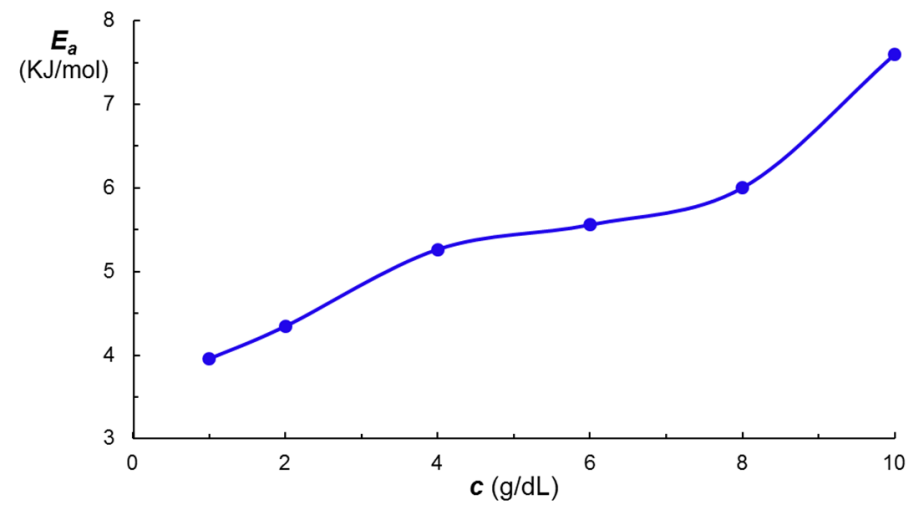

Figure 5. The activation energy of flow $\left(E_{a}\right)$ as a function of BSA concentration

\section{CONCLUSIONS}

BSA solutions are complex fluids, their behaviour being influenced by structural factors as well as by the thermodynamic and shear conditions.

At low concentrations of BSA solutions, the electroviscous effects govern the flow behaviour; at high concentrations, the balance between all intermolecular interactions and the shear forces dictates the viscosity value, wherein intermolecular attraction at high temperatures leads to a high solution viscosity. A heat denaturation of BSA occurs above $70^{\circ} \mathrm{C}$. 


\section{EXPERIMENTAL SECTION}

Bovine serum albumin (Sigma-Aldrich) solutions of different concentrations $(1 \mathrm{~g} / \mathrm{dL}, 2 \mathrm{~g} / \mathrm{dL}, 4 \mathrm{~g} / \mathrm{dL}, 6 \mathrm{~g} / \mathrm{dL}, 8 \mathrm{~g} / \mathrm{dL}, 10 \mathrm{~g} / \mathrm{dL})$ were prepared in physiological serum $(\mathrm{pH}=7.4)$ and refrigerated. They were warmed up to the working temperature and thermostated for 15 minutes before experiments were carried out.

The stationary shear flow investigations were carried out with a MCR 302 Anton-Paar rheometer equipped with Peltier device for temperature control and plane-plane geometry (the upper plate having the diameter of 50 $\mathrm{mm}$, with a gap of $500 \mu \mathrm{m}$ ). For preventing the water evaporation, it was used an anti-evaporation device, which created a saturated atmosphere in the vecinity of the sample.

\section{ACKNOWLEDGMENTS}

The financial support of European Social Fund for Regional Development, Competitiveness Operational Program Axis 1 - Project "Petru Poni Institute of Macromolecular Chemistry - Interdisciplinary Pol for Smart Specialization through Research and Innovation and Technology Transfer in Bio(nano)polymeric Materials and (Eco)Technology", InoMatPol (ID P_36_570, Contract 142/10.10.2016, cod MySMIS: 107464) is gratefully acknowledged.

\section{REFERENCES}

1. D.C. Carter; J.X. Ho; Adv. Protein Chem., 1994, 45, 153-203

2. V.A. Borzova; K.A. Markossian; N.A. Chebotareva; S.Yu. Kleymenov; N.B. Poliansky; K.O. Muranov; V.A. Stein-Margolina; V.V. Shubin; D.I. Markov; B.I. Kurganov; PLoS One, 2016, 11(4), e0153495 and references cited therein

3. P.D. Ross; A.P. Minton; J. Mol. Biol., 1977, 112, 437-452

4. L.R.S. Barbosa; M.G. Ortore; F. Spinozzi; P. Mariani; S. Bernstorff; R. Itri; Biophys. J., 2010, 98, 147-157

5. D. Hall; A.P. Minton; Biochim. Biophys. Acta, 2003, 1649(2) 127-139

6. A. Saluja; D.S. Kalonia; Int. J. Pharm., 2008, 358(1-2), 1-15

7. R. Chari; K. Jerath; A. Badkar; D.S. Kalonia; Pharm. Res., 2009, 26(12), 26072618

8. S. Yadav; J. Liu; S. J. Shire; D.S. Kalonia; J. Pharm. Sci., 2010, 99(3), 11521168 
9. J. Jezek; M. Rides; B. Derham; J. Moore; E. Cerasoli; R. Simler; B. PerezRamirez; Adv. Drug Delivery Rev., 2011, 63, 1107-1117

10. A. Oliva, A. Santovena, J. Farina, M. Llabres, J. Pharm. Biomed. Anal., 2003, 33, 145-155

11. V. Sharma; A. Jaishankar; Y.-C. Wang; G.H. McKinley; Soft Matter, 2011, 11, 5150-5160

12. E.S. Dragan; M. Bercea; L. Sacarescu; React. Funct. Polym., 2018, 124, 171180

13. L.E. Nita; A.P. Chiriac; M. Bercea; M. Asanduleasa; B.A. Wolf; Int. J. Biol. Macromol., 2017, 95, 412-420

14. S. Yadav; S.J. Shire; D.S. Kalonia; Pharm. Res., 2011, 28, 1973-1983

15. K. Aoki; K.Hiramatsu; K. Kimura; S. Kaneshina; Y. Nakamura; K. Sato; Bull. Inst. Chem. Res., Kyoto Univ., 1969, 47(4), 274-282

16. S. Chien; Science, 1970, 168, 977-979

17. S. Morariu; C.E. Brunchi; C. Hulubei; M. Bercea; Ind. Eng. Chem. Res., 2011, 50, 9451-9455

18. A. Ghirişan; S. Drăgan; C. Coţa; N.C. loica; E.-M. Nagy; V. Miclăuş; Studia UBB Chemia, 2018, LXIII(2), 53-62

19. C. Tanford; J.G. Buzzell; J. Phys. Chem., 1956, 60, 225-231

20. M. Bercea, S. Morariu, L.E. Nita, R.N. Darie, Polym. Plast. Technol. Eng., 2014, $53,1354-1361$ 